\title{
Effect of cow dung manure and SP-36 fertilizer on the quality of patchouli oil (Pogostemon cablin Benth.) planted on Ultisol
}

\author{
Syarifah Renny Fauzi ${ }^{1}$, Syakur ${ }^{2 *}$, and Syafruddin ${ }^{1}$ \\ ${ }^{1}$ Magister Agroekoteknologi Department, Faculty of Agriculture, Universitas Syiah Kuala, Indonesia \\ ${ }^{2}$ Soil Science Department, Faculty of Agriculture, Universitas Syiah Kuala, Indonesia
}

\begin{abstract}
The medical function of patchouli oil as an anti-virus allows it to be developed into a drug for COVID-19. The management of marginal soil namely Ultisol for patchouli development is very important because of its vast potential in Aceh. Therefore, the purpose of this study is to find out the effect of cow dung manure and SP-36 fertilizer on the quality of patchouli oil (Pogostemon cablin Benth.) on Ultisol. This study used factorial randomized block design with 3 replications. The first treatment factor was the dose of cow dung manure (control, 10 tonnes ha ${ }^{-1}, 20$ tonnes ha ${ }^{-1}, 30$ tonnes $\left.\mathrm{ha}^{-1}\right)$. The second treatment factor was the dose of SP-36 fertilizer (control, $100 \mathrm{~kg} \mathrm{ha}^{-1}, 200 \mathrm{~kg} \mathrm{ha}^{-1}, 300 \mathrm{~kg} \mathrm{ha}^{-1}$ ). The results showed that the treatment had no significant effect on patchouli oil yield. The highest Patchouli Alcohol obtained was $27.74 \%$ on the combination of 30 tonnes ha${ }^{1}$ cow dung manure and $300 \mathrm{~kg} \mathrm{ha}^{-1} \mathrm{SP}-36$ fertilizer.
\end{abstract}

\section{Introduction}

Patchouli plant (Pogostemon cablin Benth.) is an essential oil-producing plant. Patchouli oil serves as a binder on perfumes. In Indonesia especially in Aceh, patchouli plants have a variety of oil yields and qualities [1]. The medical function of patchouli oil as an anti-virus, allows it to be developed into a drug for Corona Virus Disease-19 (COVID-19). Ultisol has a low $\mathrm{pH}$ or tends to acid. The problem of Ultisol is low content of organic matter, low $\mathrm{pH}$ or acid (P is not available for plant), and high solubility of aluminum (Al) [2-5]. Meanwhile, It has been widely known the advantages of manure in solving various problems contained in sour soil such as Ultisol. According to [6-9], the application of manure in Ultisol was able to support the growth and yield of crops and improve the quality of Ultisol.

There have been many studies state that combining organic matter with mineral fertilizer $\mathrm{P}$ can support the growth and yield of plant in Ultisol. According to $[10,2,11,12,13]$, the combination of organic matter with $\mathrm{P}$ mineral fertilizer had a positive impact in improving Ultisol as well as improving the growth and yield of plant. The use of cow manure as a source of organic matter was chosen. Because cow manure has been generally known to be a superior source of organic material to support the organization and crop yield. Then combined with fertilizer SP-36. The improvement of marginal soil namely Ultisol using cow

* Corresponding author: syakur@unsyiah.ac.id 
dung manure and SP-36 fertilizer for the quality of patchouli oil is very important because of its vast potential in Aceh. So that, the purpose of this study is to find out the effect of cow dung manure and SP-36 fertilizer on the quality of patchouli oil (Pogostemon cablin Benth.) on Ultisol.

\section{Materials and method}

\subsection{Planting}

Plant material (cuttings) used superior variety namely Lhokseumawe variety. Patchouli seedlings were reproduced with cuttings shoots. The shoots taken had 4 books with 4 buds or 4 leaves. Then, cuttings were sowed in polybags. The polybag used had a volume of 500 $\mathrm{g}$ of soil. Mixture of soil and manure with a ratio of 2:1 put in a polybag. Planted cuttings were watered. After that, the polybags where cuttings were planted were covered using airtight plastic as high as 1 meter. Plastic was attached to bamboo wood shaped like a convexity. After 20 days of steaming, the hood covering the patchouli seedlings was opened. Then, the seedlings were watered daily in the morning and evening. After the age of seedlings reached 30 Days After Seedlings (DAS), patchouli seedlings were moved to be planted in the field.

The planting media used was Ultisol taken from Jalin Village, Kota Jantho, Aceh Besar at coordinates $5^{\circ} 16^{\prime} 58.41^{\prime \prime} \mathrm{LU} 95^{\circ} 37^{\prime} 51.82^{\prime \prime}$ BT. Soil was taken on the top soil $1-20 \mathrm{~cm}$. The soil was cleaned of litter and pounded to crush, then sifted using a sieve that measured $5 \times 5$ $\mathrm{mm}$ for uniform size. The sifted soil was put in a polybag that had a volume of $20 \mathrm{~kg}$ of soil. The soil was put in a polybag as much as $3 / 4$ part of polybag. Furthermore, the polybags that were filled with soil, were placed in accordance with the composition of the research plan. Around the polybag was attached a paranet to protect the patchouli from the wind. Plants were moved when the patchouli was already 30 DAS into a polybag filled with $20 \mathrm{~kg}$ of soil. In this study, there were 16 combinations of treatment with 3 replications. So that, there were 48 experimental units. The range among experimental units was $100 \mathrm{~cm}$ x $100 \mathrm{~cm}$. Planting was done as much as 1 seedling for 1 polybag.

The way of planting was by making planting holes in the soil in $20 \mathrm{~kg}$ soil of polybag. The planting hole was made as big as the size of a nursery polybag. The nursery polybag was torn and kept from breaking the soil. Because if the soil breaks, the roots will be disturbed. So, it can make patchouli seedlings wither when moving planting. Furthermore, patchouli seedlings along with nursery planting media were inserted into the planting hole. After that, the planting hole was stockpiled using Ultisol. It was given basic fertilizers namely urea, ZA and $\mathrm{KCl}$. The basic fertilizer doses can be seen in Table 1.

Table 1. Basic fertilizer doses for patchouli planting

\begin{tabular}{|c|c|c|c|}
\hline Fertilization Time & Urea & $\mathbf{Z A}$ & $\mathrm{KCl}$ \\
\hline $\begin{array}{l}30 \text { Days After } \\
\text { Transplanting }\end{array}$ & $\begin{array}{c}75 \mathrm{~kg}^{\mathrm{urea} \mathrm{ha}^{-1}(0.75 \mathrm{~g}} \\
\text { per polybag })\end{array}$ & $\begin{array}{c}75 \mathrm{~kg} \mathrm{ZA} \mathrm{ha}^{-1}(0.75 \mathrm{~g} \\
\text { per polybag })\end{array}$ & $\begin{array}{l}50 \mathrm{~kg} \mathrm{KCl} \mathrm{ha}^{-1}(0.5 \mathrm{~g} \\
\text { per polybag })\end{array}$ \\
\hline $\begin{array}{l}60 \text { Days After } \\
\text { Transplanting }\end{array}$ & $\begin{array}{c}50 \mathrm{~kg}^{\mathrm{kgea} \mathrm{ha}} \mathrm{h}^{-1}(0.5 \mathrm{~g} \\
\text { per polybag })\end{array}$ & $\begin{array}{c}50 \mathrm{~kg} \mathrm{ZA} \mathrm{ha}^{-1}(0.5 \mathrm{~g} \\
\text { per polybag) }\end{array}$ & $\begin{array}{c}50 \mathrm{~kg} \mathrm{KCl} \mathrm{ha}^{-1}(0.5 \mathrm{~g} \\
\text { per polybag) }\end{array}$ \\
\hline $\begin{array}{l}90 \text { Days After } \\
\text { Transplanting }\end{array}$ & $\begin{array}{l}25 \mathrm{~kg} u r e a ~ h a^{-1}(0.25 \mathrm{~g} \\
\text { per polybag })\end{array}$ & $\begin{array}{c}25 \mathrm{~kg} \mathrm{ZA} \mathrm{ha}^{-1}(0.25 \mathrm{~g} \\
\text { per polybag })\end{array}$ & $\begin{array}{c}12.5 \mathrm{~kg} \mathrm{KCl} \mathrm{ha}^{-1}(0.125 \\
\text { g per polybag })\end{array}$ \\
\hline
\end{tabular}

\subsection{Treatment and harvesting}

Harvesting was done when patchouli was already 150 DAT or 5 months after transplanting. The fertilizer treatments can be seen in Table 2. 
Table 2. The fertilizer treatments on patchouli planting

\begin{tabular}{|c|c|c|c|}
\hline \multirow{2}{*}{ Fertilization Time } & \multicolumn{3}{|c|}{ The treatment of cow dung manure } \\
\hline & K1 & K2 & K3 \\
\hline \multirow[t]{3}{*}{ One week before planting } & $\begin{array}{c}10 \text { tons ha }^{-1}(100 \mathrm{~g} \\
\text { per polybag- }\end{array}$ & $\begin{array}{c}20 \text { tons ha }^{-1}(200 \mathrm{~g} \\
\text { per polybag })\end{array}$ & $\begin{array}{c}30 \text { tons ha }^{-1}(300 \mathrm{~g} \\
\text { per polybag })\end{array}$ \\
\hline & \multicolumn{3}{|c|}{ The treatment of SP-36 fertilizer } \\
\hline & $\mathrm{P} 1$ & $\mathrm{P} 2$ & $\mathrm{P} 3$ \\
\hline Transplanting day & $\begin{array}{c}100 \mathrm{~kg} \mathrm{ha}^{-1}(1 \mathrm{~g} \text { per } \\
\text { polybag })\end{array}$ & $\begin{array}{c}200 \mathrm{~kg} \mathrm{ha}^{-1}\left(2 \mathrm{~g}_{\text {per }}\right. \\
\text { polybag })\end{array}$ & $\begin{array}{l}300 \mathrm{~kg} \mathrm{ha}^{-1}(2 \mathrm{~g} \\
\text { per polybag })\end{array}$ \\
\hline
\end{tabular}

\subsection{Oil yield (\%) and patchouli alcohol (PA\%)}

Analysis of oil yield (\%) was conducted at the Atsiri Research Center, Syiah Kuala University, Banda Aceh. Patchouli plants that have been wind-dryed for 1 week, then chopped using wooden scissors up to the size of $2 \mathrm{~cm}$. After that, the distillation process was carried out. Distillation was done using a distilled pumpkin to obtain patchouli oil. Distillation was done using steam distillation techniques. The oil was produced through the evaporation process.

Evaporation produced water mixed with patchouli oil. After that, oil and water were accommodated in the holding media after passing through the cooling process in the condenser. Then, the oil was separated from the water through the filtration process using a monel cloth. The filtered oil was accommodated in a $10 \mathrm{ml}$ glass bottle. As a result, pure patchouli oil was obtained. To analyze the yield of patchouli oil, patchouli plants were weighed so that the weight of patchouli raw materials $(\mathrm{kg})$ was obtained. Then, it was weighed the weight of patchouli oil yield $(\mathrm{kg})$. After that, it was incorporated into the formula below.

$$
R \%=\frac{M}{B} \times 100 \%
$$

Where :

$\mathrm{R}=$ Oil yield $(\%)$

$\mathrm{M}=$ Weight of patchouli oil yield $(\mathrm{kg})$

$\mathrm{B}=$ Weight of patchouli raw materials $(\mathrm{kg})$

Patchouli Alcohol (PA\%) was analyzed on 16 patchouli oil samples on 16 treatments. The analysis was conducted at Laboratory of UPTD Goods Quality Standard Testing Center, Banda Aceh. PA\% was analyzed using Gas Chromatography-Mass Spectrometry (GC-MS).

\subsection{Statistical analysis}

The data on composting time was statistically analysed for Analysis of Variance (ANOVA). Significant differences between mean values were determined using Duncan Multiple Range Test $(\mathrm{P}=0.05)$. 


\section{Results and discussion}

\subsection{Effect of cow dung manure dose and SP-36 fertilizer dose on patchouli oil yield}

The average yield of patchouli oil due to the effect of cow dung manure dose and SP-36 fertilizer dose can be seen in Table 3. The results of the analysis showed that patchouli oil yield tends to be higher in the application of cow dung manure dose 10 tons ha ${ }^{-1}(100 \mathrm{~g}$ per polybag) namely $1.73 \%$, and at the application of SP-36 fertilizer $300 \mathrm{~kg} \mathrm{ha}^{-1}$ (3 g per polybag) namely $1.79 \%$. Although, statistically no different from other treatments.

This is natural, because the patchouli studied was planted in the planting media derived from marginal soil namely Ultisol. Thus, it is suspected that the treatment given has not been able to affect the yield of patchouli oil. However, based on the description of Lhokseumawe patchouli variety issued by [14], that the patchouli of Lhokseumawe variety is only able to produce patchouli oil yield ranging from $2.00-4.14 \%$ only. Thus, the highest patchouli oil yield produced from both treatment factors is $1.73 \%$ and $1.79 \%$ close to the standard patchouli oil yield of Lhokseumawe variety that has been determined by the [14].

Table 3. The average yield of patchouli oil due to the effect of cow dung manure dose and SP-36 fertilizer dose

\begin{tabular}{|l|c|}
\hline \multicolumn{1}{|c|}{ Cow manure dose } & Patchouli oil yield (\%) \\
\hline Control & 1.69 \\
\hline 10 tons ha ${ }^{-1}(100 \mathrm{~g}$ per polybag $)$ & 1.73 \\
\hline 20 tons ha ${ }^{-1}(200 \mathrm{~g}$ per polybag $)$ & 1.56 \\
\hline 30 tons ha $(300 \mathrm{~g}$ per polybag) & $1, .56$ \\
\hline SP-36 fertilizer dose & Patchouli Oil Yield $(\%)$ \\
\hline Control & 1.49 \\
\hline $100 \mathrm{~kg} \mathrm{ha}^{-1}(1 \mathrm{~g}$ per polybag $)$ & 1.62 \\
\hline $200 \mathrm{~kg} \mathrm{ha}^{-1}(2 \mathrm{~g}$ per polybag $)$ & 1.64 \\
\hline $300 \mathrm{~kg} \mathrm{ha}^{-1}(3 \mathrm{~g}$ per polybag $)$ & 1.79 \\
\hline
\end{tabular}

Therefore, further research is needed related to cow dung manure dose and SP-36 fertilizer dose that tends to be higher in order to influence the yield of patchouli oil grown in Ultisol. Then, if possible, it can achieve patchouli oil yield that can exceed the standard patchouli oil yield of Lhokseumawe variety that has been set.

\subsection{Patchouli alcohol (PA\%)}

After the distillation process of patchouli oil, the resulting patchouli oil was tested in the laboratory to check the level of Patcholi Alcohol (PA\%) of any treatment given. The results of the analysis are listed in Table 4. The highest patchouli oil test result was in the combination of K3P3 treatment, namely in the combination of cow dung manure dose treatment 30 tons ha ${ }^{-1}$ (300 g per polybag) with the application of SP-36 fertilizer dose 300 $\mathrm{kg} \mathrm{ha}^{-1}$ (3 g per polybag) by $27.74 \%$.

Indeed, the resulting PA\% rate is still below Indonesian National Standard (SNI) that has been set namely $30 \%$. However, based on the description of Lhokseumawe patchouli variety issued by [14], that the patchouli of Lhokseumawe variety has a PA\% content ranging from $29.11-34.46 \%$. Thus, the PA\% rate of $27.74 \%$ is close to the standard set.

However, more optimal efforts are needed related to the cultivation of patchouli in Ultisol, so that the expected PA\% levels can be achieved. In fact, it is able to exceed the PA\% level that has been set by SNI. However, currently there is also a fractionation tool to increase the 
PA\% content of patchouli oil in Laboratory of Atsiri Research Center-Pusat Unggulan Iptek Perguruan Tinggi (PUI-PT) Nilam Aceh, Universitas Syiah Kuala. Thus, to get patchouli oil with a higher PA\% content becomes easier.

Currently, what needs to be considered is the effort how to be able to produce a much higher patchouli oil yield to further multiply the stock of patchouli oil. Related to PA\%, if $\mathrm{PA} \%$ patchouli oil has not reached the standard set, it can be done fractionation process to be able to get the desired PA\% content. But, if only through the efforts made in the process of patchouli cultivation has been able to produce expected patchouli oil yield and preferred PA\% content, it is much better.

Table 4. The analysis result of Patchouli Alcohol (PA) of patchouli oil (\%)

\begin{tabular}{|c|c|c|c|}
\hline Number & Treatment & Analysis result & Rate of SNI 06-3953-1995 \\
\hline 1. & K0P0 & 25.35 & \multirow{16}{*}{$\begin{array}{c}\text { Minimum } 30 \\
\text { GCMS }\end{array}$} \\
\hline 2. & K0P1 & 20.79 & \\
\hline 3. & K0P2 & 24.88 & \\
\hline 4. & K0P3 & 22.49 & \\
\hline 5. & K1P0 & 26.36 & \\
\hline 6. & K1P1 & 23.70 & \\
\hline 7. & K1P2 & 23.72 & \\
\hline 8. & K1P3 & 22.74 & \\
\hline 9. & K2P0 & 23.79 & \\
\hline 10. & K2P1 & 26.81 & \\
\hline 11. & K2P2 & 23.60 & \\
\hline 12. & K2P3 & 21.97 & \\
\hline 13. & K3P0 & 21.74 & \\
\hline 14. & K3P1 & 25.12 & \\
\hline 15. & K3P2 & 23.04 & \\
\hline 16. & K3P3 & 27.74 & \\
\hline
\end{tabular}

\section{Conclusion}

The dose of cow dung manure 10 tons $\mathrm{ha}^{-1}(100 \mathrm{~g}$ per polybag) produced the highest oil yield of $1.73 \%$. The fertilizer dose of SP-36 $300 \mathrm{~kg} \mathrm{ha}^{-1}$ (3 g per polybag) gained the highest oil yield of $1.79 \%$. Meanwhile, the highest $\mathrm{PA} \%$ obtained was $27.74 \%$ in the treatment combination of cow dung manure doses 30 tons ha $\mathrm{ha}^{-1}$ (300 g per polybag) and the fertilizer dose of SP-36 $300 \mathrm{~kg} \mathrm{ha}^{-1}$ (3 $\mathrm{g}$ per polybag).

I would like to express my gratitude to Lembaga Pengelola Dana Pendidikan (LPDP), the Ministry of Finance of Republic of Indonesia that funded research and publication of this paper. Then, to Atsiri Research Center - Pusat Unggulan Iptek Perguruan Tinggi (PUI-PT) Nilam Aceh, Universitas Syiah Kuala which facilitated the place of research.

\section{References}

1. H. Hariyani, E. Widaryanto, N. Herlina, J. Produksi Tan 3, 3 (2015).

2. Hermawan, A. Sabaruddin, Marsi, R. Hayati, Warsito, Agrivita 36, 2 (2014).

3. Syahputra, E. Fauzi, Razali, J. Agroekoteknologi 4, 1 (2015).

4. A.A. Fatai, J. Shamshuddin, C.I. Fauziah, O. Radziah, M. Bohluli, Formation and characteristics of an Ultisol in Peninsular Malaysia utilized for oil palm production, Solid Earth Discuss, Malaysia (2017)

5. R. Wilujeng, E. Handayanto, J. Tanah dan Sumberdaya Lahan 6, 1 (2019). 
6. J. Achieng, O.G. Ouma, G. Odhiambo, F. Muyekho, Agric. and Bio. J. of North America 1, 4 (2010).

7. Burhanuddin, Nurmansyah, Bul. Littro. 21, 2 (2010).

8. S. Huang, W. Zhang, X. Yu, Q. Huang, Agric. Eco. \& Environ 138, 1 - 2 (2010).

9. C.I. Okonkwo, C. Onyibe, J. Nwite, T.S. Igwe, C. Njoku, C.N. Mbah, International Research J. of Agric. Sci. and Soil Sci. 2, 2 (2012).

10. M.C. Soplanit, R. Soplanit, Agrologia 1, 1 (2012).

11. A. Kusumastuti, J. Penelitian Pertanian Terapan 14, 3 (2014).

12. A. Wahyudin, T. Nurmala, R.D. Rahmawati, J. Kultivasi 14, 2 (2015).

13. A. Wahyudin, B.N. Fitriatin, F.Y. Wicaksono, Ruminta, A. Rahadiyan, J. Kultivasi 16, 1 (2017).

14. Balai Penelitian Tanaman Rempah dan Obat, Nilam Varietas Lhokseumawe, http://balittro.litbang.pertanian.go.id/?p=1647, accessed in 12 Juli 2020 (2017). 